\title{
Adiponectin and Leptin Adipocytokines in Metabolic Syndrome: What Is Its Importance?
}

\author{
María Luz Gunturiz Albarracín ${ }^{a}$ Ana Yibby Forero Torres ${ }^{b}$ \\ aProject Bank Team, Public Health Research Division, National Institute of Health, Bogotá, Colombia;

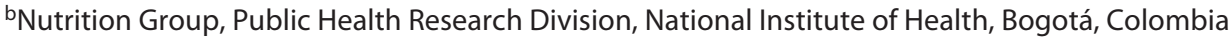

\section{Keywords}

Metabolic syndrome $\cdot$ Leptin · Adiponectin .

Cardiometabolic diseases · Adipocytokines

\begin{abstract}
The global obesity epidemic has motivated a large number of investigations related to adipose tissue. Within the advances in this area, a variety of factors secreted by adipose tissue and with regulatory activity on caloric intake, energy expenditure, reproduction, locomotor activity, glycidic and lipid metabolism, immune response, and bone physiology have been described.

Among these adipocyte hormones, collectively called "adipokines" or "adipocytokines," leptin (LEP) and adiponectin are addressed in this review. The regulation of adipocytokines is altered in diseases such as obesity, atherosclerosis, type 2 diabetes mellitus, and metabolic syndrome (MS) due to the increase in the mass of white adipose tissue. LEP and adiponectin have a broad spectrum of functions in regulating metabolism and are an important link between obesity and MS. Because these adipocytokines have opposite effects on subclinical inflammation and insulin resistance, it has been suggested that the combined use of these 2 adipocytokines may work as a better biomarker in the diagnosis of MS than using them individually.

In this review, we address the characteristics and main functions of adipocytokines derived from adipose tissue such as
\end{abstract}

karger@karger.com www.karger.com/dde

Karger"

BOPEN ACCESS
(C) 2020 The Author(s)

Published by S. Karger AG, Basel

This article is licensed under the Creative Commons AttributionNonCommercial-NoDerivatives 4.0 International License (CC BYNC-ND) (http://www.karger.com/Services/OpenAccessLicense). Usage and distribution for commercial purposes as well as any distribution of modified material requires written permission. adiponectin and LEP, which in the Colombian context could give good guidance for the management of MS, especially in populations of children and adolescents.

(C) 2020 The Author(s)

Published by S. Karger AG, Basel

\section{Introduction}

The nutritional condition is the balance between the caloric intake and energy expenditure of an individual, an equilibrium involving physical, genetic, biological, cultural, psycho-socioeconomic, and environmental factors. These factors may cause an insufficient or excessive consumption of nutrients or an inadequate diet; the latter can cause obesity.

What is really important in obesity related to cardiovascular risk is the distribution of body fat or the differentiation of adipose from other tissues (or essential body fat from storage body fat). It can be used as clinical tools to identify the risk of metabolic disorders in children and adolescents [1].

Obesity is a multifactorial disease that occurs from the interaction between a genetic predisposition and the presence of certain external factors (caused by both genetic and non-genetic factors) [2,3]. It is characterized by an increase in body weight beyond the needs of the skeletal physical structure, as a result of the excessive accumulation of body fat [4-7]. Usually is defined in adults as 
a BMI $>30 \mathrm{~kg} / \mathrm{m}^{2}$, obesity has become a leading public health concern for both genders, all ages, and all ethnic groups $[8,9]$.

Similarly, obesity is a cardiovascular risk factor that acts passively by increasing the load on the heart and actively by causing an alteration in the plasma concentrations of various molecular factors that are produced by adipose tissue and that have cardiovascular effects, in addition to a regulatory role in energy metabolism, which determines that fat is a real endocrine organ [10-13].

The high prevalence of obesity leads to an increased incidence of type 2 diabetes mellitus (DM2) and the development of cardiovascular diseases (CVD) in children. Predominant abdominal adipose tissue distribution (central obesity) in adults and children is positively correlated with arterial hypertension (HTA), dyslipidemia, and alterations in glucose metabolism, including insulin resistance, glucose intolerance, and DM2 [14]. However, health risks are more associated with central obesity than with total obesity, as evidenced by some studies that showed that visceral obesity in children increases the risk of developing CVDs [14-16].

Adipose tissue was initially classified as an energy storage organ, but today, it is known to function as a major endocrine system that secretes adipocytokines or adipokines, growth factors, cytokines, and chemokines. The pattern of adipocytokine secretion appears to vary according to the deposit of adipose tissue and depends on the energy state of the adipose deposit $[17,18]$.

Adipose tissue plays essential roles in maintaining lipid and glucose homeostasis; in obesity, the adipocytes are dysfunctional with excessive secretion of multiple proinflammatory adipocytokines, contributing to a chronic inflammatory reaction and promote the progression of metabolic and cardiovascular complications [17-19]. These adipocytokines include proteins that modify insulin sensitivity (acylation stimulating protein, tumor necrosis factor a [TNF-a], IL-6, resistin, visfatin, apelin, omentin, chemerin, leptin [LEP], and adiponectin) and proteins that have known effects on vascularity (angiotensinogen and the plasminogen inhibitor protein, PAI1) among others [20-23].

Adipocytokines are bioactive proteins synthesized and secreted by adipose tissue, which play an important role and are important mediators of various metabolic processes such as the regulation of energy metabolism, neuroendocrine and immune function, vascular remodeling, angiogenesis, fatty acid oxidation, de novo lipogenesis, gluconeogenesis, glucose uptake, insulin signaling, and energy expenditure in metabolically active tissues such as the liver, skeletal muscle, and the brain. These proteins can act locally, through autocrine/paracrine mechanisms, or systemically, through endocrine effects $[18,19,24]$.

Tissues other than adipose tissue secrete some adipocytokines, and the contribution of this tissue to circulating adipocytokine concentrations has not been established exactly. Furthermore, little is known regarding the molecular mechanisms involved in the biosynthesis and exocytosis of these bioactive proteins, although there is evidence of some regulatory mechanisms in the secretory pathways in adipocytes $[20,25]$.

\section{Adiponectin and LEP: Descriptions and Functions}

\section{Adiponectin}

Adiponectin, which is also known as adipoQ, ACRp30, apM1, and GBP28, is made up of a collagen tail and a globular head, which forms dimers and trimers; these high-molecular-weight complexes are found in the circulation, although the bioactive form has not been determined. Adiponectin exerts its function by binding to its AdipoR1 and AdipoR2 receptors [20, 26, 27].

Adiponectin is a $30-\mathrm{kDa}$ protein, synthesized mainly by adipocytes and cardiomyocytes $[13,24,28]$. This hormone circulates abundantly in human plasma and its concentration is $0.01 \%$ of the total plasma protein [29]. One of the most important roles of this hormone is to improve insulin resistance by increasing the oxidation of fatty acids in adipose tissue and decreasing the concentrations of these fatty acids in the blood and the intracellular content of triglycerides (TG) in the liver and muscle. Furthermore, it has a protective function in the processes of atherosclerosis [30]. Their plasma concentrations have been reported to be decreased in states of insulin resistance, such as obesity and DM2, as well as in patients with coronary heart disease [13, 31-33].

Adiponectin, is directly related to insulin sensitivity, abdominal obesity, and changes in lipid profile (particularly low levels of high-density lipoprotein cholesterol [HDL-C]). In addition, there is an inverse relationship between vascular inflammation and plasma levels of this hormone. A direct relationship has also been observed between reduced plasma concentrations of adiponectin and the extent of atherosclerosis, and lower levels of this hormone have been reported in men with ischemic heart disease [34]. The plasma adiponectin concentration is high and represents $0.01 \%$ of the total plasma protein $[29,35]$.

Although fatty tissue is the main origin of adiponectin, its synthesis has been described in bone marrow cells, 
skeletal muscle cells, and hepatocytes, among others. Adiponectin exerts its biological actions through 2 receptors that are predominantly expressed in the liver (AdipoR2) and in skeletal muscle (AdipoR1). These receptors transduce signals through intracellular activation of adenosine monophosphate-dependent protein kinase (AMPK) and activate peroxisome proliferator-activated receptor gamma (PPAR $\gamma$ ) and probably other intracellular signal transduction pathways, leading to increased fatty acid oxidation and a reduction in hepatic glucose synthesis [36].

Some studies have described its synthesis and secretion by human and murine cardiomyocytes (which also express its 2 types of receptors), where it induces uptake of glucose and fatty acids. Ding et al. [37] have shown that the synthesis of this hormone in cardiac tissue, as in fatty tissue, is stimulated by the action of rosiglitazone, which acts as an agonist for PPAR $\gamma$ receptors [28, 35, 37].

In myocytes, it favors glucose uptake and fatty acid oxidation, stimulating the phosphorylation of acetyl coenzyme-A carboxylase [38]. Adiponectin inhibits the early stages of atherosclerosis by reducing the expression of adhesion molecules in endothelial cells, the transformation of macrophages into foamy cells, the expression of TNF- $\alpha$, and the proliferation of cells from smooth muscle tissue. Different states of insulin resistance, such as obesity and DM2, or the development of CVDs has been associated with a reduction or low levels of plasma adiponectin [39]. Additionally, adiponectin is also capable of limiting the progression of cardiac hypertrophy and of exerting a protective effect against myocardial damage induced by ischemia-reperfusion phenomena, as well as reducing the risk of remodeling and cardiac dysfunction after myocardial infarction in experimental mouse models $[40,41]$.

A relationship between hypoadiponectinemia and the risk of developing hypertension has also been described. The reduction of plasma adiponectin predicts the appearance of hypertension independently of other factors such as obesity, age, insulin resistance, and inflammatory status determined by plasma concentration of $\mathrm{C}$-reactive protein [42-44].

On the other hand, various studies have been published that describe a correlation between plasma hormone concentration and the risk of suffering any of the forms of clinical presentation of ischemic heart disease, particularly acute coronary syndrome. Plasma adiponectin concentration is inversely correlated with the risk of suffering an acute coronary syndrome with or without ST segment elevation, both in the general population and in diabetics [45-47]. On the other hand, the plasma concen- tration of adiponectin is sharply reduced after myocardial infarction and is also related to the complexity of coronary lesions in patients with clinical ischemic heart disease. However, higher mortality from any cause and higher risk of myocardial infarction have been described in ischemic patients with higher concentrations of adiponectin, due to an imbalance in the regulation of adiponectin production, with an increase in its synthesis that is insufficient to compensate for the advanced inflammatory process $[48-51]$.

\section{Leptin}

LEP is the first adipocytokine identified and discovered in 1994 by Friedman and Halaas [52, 53]. It is a 167 -amino acid protein including a 21 amino acid signal peptide. Its 3-dimensional structure has $4 \alpha$-helices and a disulfide bridge between cysteine at positions 96 and 146, the latter being necessary for the biological activity of the hormone. It is secreted by adipocytes of white adipose tissue and its tertiary structure is similar to that of longchain helical cytokines, such as inhibitory factor of leukemia and interleukin $[54,55]$.

This hormone is secreted into the circulation and binds to specific cell surface receptors, triggering the activation of specific signaling pathways intracellular [56, 57]. Other tissues such as placenta, ovary, and gastric mucosa could produce LEP in small quantities; however, the physiological significance or pathological significance of these findings remains unknown [57-59].

LEP acts through the activation of its receptor (ObR) located in the hypothalamus in the central nervous system and at the peripheral level. Receptors possess at least 6 isoforms, which are responsible for LEP transport (ObRa, ObRb, and $\mathrm{ObRc}$ ) and signaling (ObRd, ObRe, and ObRf) [60]. Initially, it was found that obese subjects had elevated serum LEP concentrations, which suggested the study of "insulin resistance" as the origin and/or maintenance of obesity, then it was evidenced that said finding was completely correct in those with congenital LEP deficiency [61, 62].

The amount is directly proportional to the mass of adipose tissue, although it can also be secreted by immunocompetent and endothelial cells [57, 63]. LEP circulates together with the soluble form of its receptor and exerts its function by binding with its receptors (ObR), ObRb, which activates the signaling pathway of the Janus kinasesignal transducer and activator of transcription proteins (JAK-STATs) system $[20,64]$.

LEP participates in the long-term normal regulation of food intake, body weight, energy expenditure, and neuro- 
Table 1. Some characteristics and functions of adiponectin and leptin (LEP)

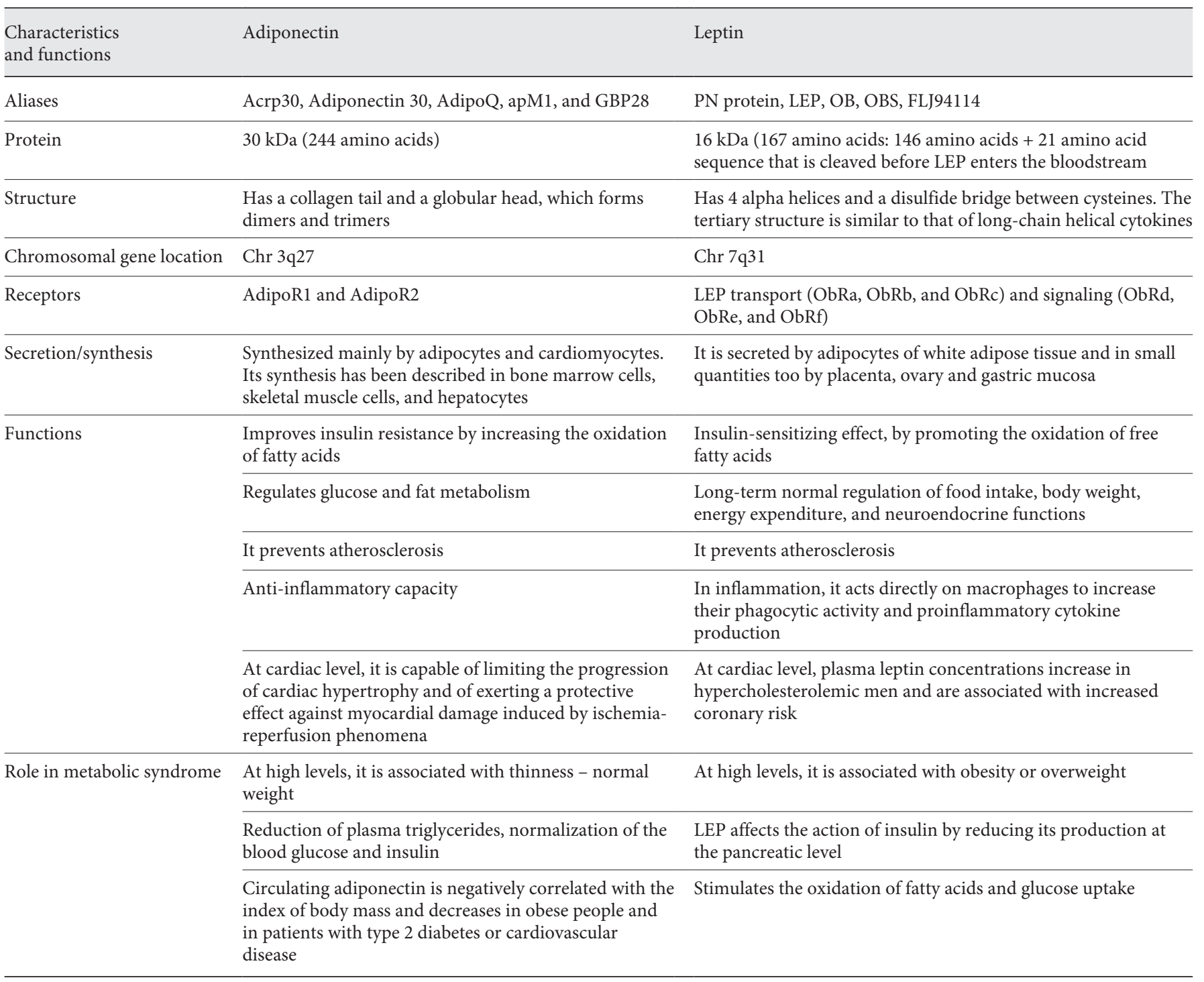

endocrine functions. However, it is contradictory that LEP is overexpressed in white adipose tissue in most of the obese, which has led to the development of the concept of LEP resistance. At the physiological level, LEP induces an insulin-sensitizing effect by promoting the oxidation of free fatty acids and reducing the accumulation of ectopic fat in non-adipose tissues $[65,66]$, and at the molecular level, this effect is directly mediated by LEP through the activation of adenosine monophosphate-dependent protein kinase in skeletal muscle and indirectly in the axis of the hypothalamic sympathetic nervous system, favoring the inhibition of the entry of fatty acids into the mitochondria by malonyl CoA and the oxidation of fatty acids [67-69]. The mecha- nism by which LEP resistance occurs may be the induction of the cytokine 3 signaling suppressor (SOCS-3), which can inhibit intracellular LEP signaling [20, 70].

In inflammation, LEP acts directly on macrophages to increase their phagocytic activity and proinflammatory cytokine production [71-73]. It has also been implicated in inflammation associated with atherosclerosis and metabolic syndrome (MS) [74]. LEP acts as a signal in the regulation of insulin sensitivity at the whole level and resistance to LEP is itself one of the causal factors of cardiovascular complications in obesity [20].

There is an association between plasma LEP concentrations and classic cardiovascular risk factors, insulin re- 
sistance, the presence of MS, and inflammatory markers, even when the proportion of body fat is within the normal range. Plasma LEP concentrations increase in hypercholesterolemic men and are associated with increased coronary risk [75-79].

For DM2, no alterations in LEP metabolism have been found and its serum levels are similar to those found in non-diabetic individuals. There is a relationship between high levels of LEP and a higher prevalence of diabetic retinopathy, but not with diabetic nephropathy.

LEP stimulates the release of nitric oxide by the pituitary, which increases the probability of HTA and CVD in obese people since these people have high levels of angiotensinogen linked to obesity that predisposes to these pathologies [80]. Table 1 summarizes the main characteristics and functions of adipocytokines, adiponectin and LEP.

\section{Adipocytokines in MS: What Is Its Importance?}

MS is defined as a pool of metabolic disorders including obesity, raised blood pressure, dyslipidemia, and elevated fasting glucose, among others. MS is one of the most important complications of excess weight, with an increase in the prevalence of obesity and overweight in children and adolescents. The risk factors that characterize MS are obesity of central or abdominal predominance, hypertension, hypertriglyceridemia, hyperglycemia, and decrease in the cholesterol bound to HDLs [81, 82].

This syndrome may be of special interest because of the increased prevalence with age [83-85]. In addition to the predominant criteria to diagnose MS, it is associated with other metabolic abnormalities related to CVDs such as plasma increases in plasminogen activating factor and fibrinogen, hyperuricemia, elevated levels of C-reactive protein, hyperhomocysteinemia, increase in the expression of TNF- $\alpha$ in adipose tissue, and decreased concentrations of adiponectin [82, 85-87].

High concentrations of free fatty acids, particularly triglyceride, secondary to increased hydrolysis, trigger elevated LDL and decreased HDL, leading to dyslipidemia and liver lipotoxicity [88]. The increase in the synthesis of adipocytokines leads to dysfunction in insulin signaling, generating hyperinsulinemia and a state of insulin resistance, closely associated with DM2 [62, 89, 90]. On the other hand, the adipocyte produces several cytokines that intervene in the local and systemic inflammatory process triggered due to obesity and that are directly related to the development of MS.

Adipocytokines in Metabolic Syndrome
Adipocytokines intervene in different events that can lead to the development of MS. Insulin resistance is a key condition in disease progression and different adipocytokines like LEP, resistin, TNF- $\alpha$, and IL-6 induce such resistance directly by avoiding signal transduction produced by insulin, thereby inhibiting the transcription and translocation of glucose receptors. The resulting hyperglycemia leads to increased inflammatory process due to the production of reactive oxygen species. Similarly, hyperinsulinemia secondary associated to resistance causes defects in phagocytic cells, increasing the circulation of bacterial antigens, which have the capacity to activate leukocytes and adipocytes that release proinflammatory cytokines; this being another mechanism of inflammation [91-93].

Adipocytokines have various effects on MS, which can be arbitrarily divided into pro-inflammatory and anti-inflammatory effects. That classification being imprecise for certain adipocytokines that have ambiguous actions as is the case with vaspin, visfatin, omentin, IL-15, and TGF- $\beta$. LEP and adiponectin have opposite effects on subclinical inflammation and insulin resistance, but both are involved in the development of MS.

Several studies indicate that there is a close relationship between adiponectin and the components of the MS (hypertension, dyslipidemia and intolerance to carbohydrates). Plasma adiponectin concentration shows an inverse correlation with BMI, mainly with visceral adiposity and insulin resistance, which increases with weight and with drugs that sensitize tissues to the actions of insulin [36]. A reduction in adiponectin secretion by proinflammatory cytokines has been observed in cultured adipocytes [94], indicating that inflammation may be a contributing factor to hypoadiponectinemia in states of obesity and insulin resistance. On the other hand, physical exercise increases the circulating amount of the hormone and the expression of its receptors in muscle, with the consequent increase in insulin sensitivity and the disappearance or attenuation of the components of the MS $[35,95]$.

At the metabolic level, the effects of adiponectin are mediated by increased protein kinase A activity, whose activation induces PPAR $\gamma$ expression, as well as the enzymes of the oxidation cascade of fatty acids and other proteins involved in glucose uptake, which would explain the increase in insulin activity induced by this hormone and through the same mechanism, the inhibition of enzymes of the gluconeogenesis pathway occurs $[36,38,96$, 97]. On the other hand, its levels in plasma are inversely proportional to the mass of adipose tissue and are re-

Dubai Diabetes Endocrinol J 2020;26:93-102 DOI: $10.1159 / 000510521$ 


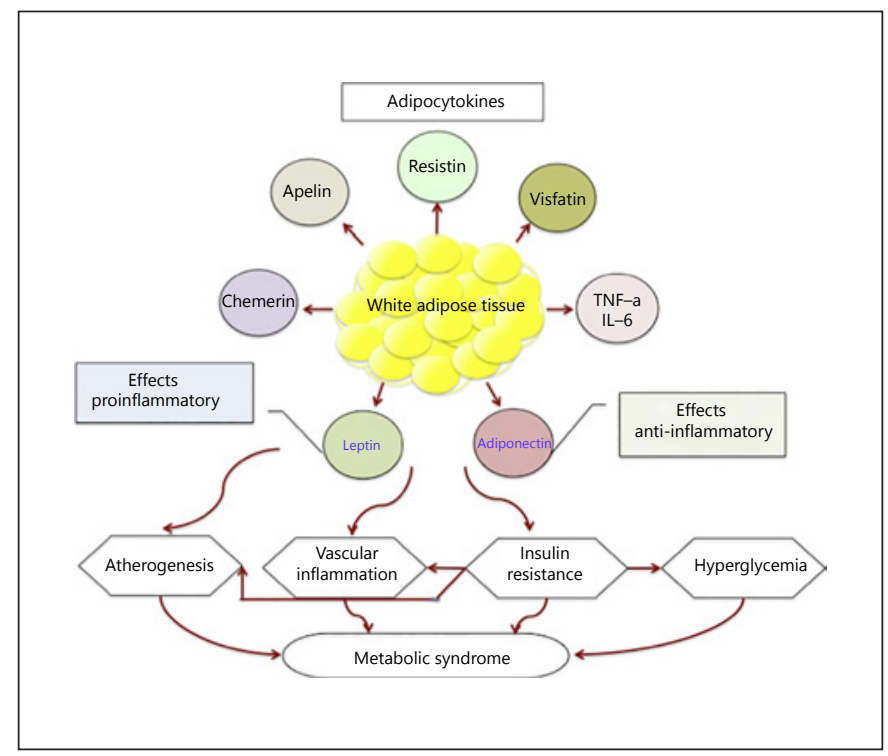

Fig. 1. Some functions of adipocytokines. Several of the different adipocytokines produced by white adipose tissue are shown, as well as some functions they have in inflammatory processes, insulin resistance, and atherogenesis, and their correlation with metabolic syndrome.

duced in patients with MS presenting resistance to insulin and DM2; even more, its levels increase with exercise, weight loss, and thiazolidinedione therapy. Its discharge is reduced by effects of insulin, LEP, and pro-inflammatory cytokines, which could explain its relationship with obesity in which there is hyperinsulinemia, hyperleptinemia, and a state of chronic inflammation induced by the increase in the mass of adipose tissue $[93,98]$.

The chronic hyperreactivity of the sympathetic nervous system as well as the activation of the renin-angiotensin-aldosterone axis could be associated with the pathophysiological mechanisms of HTA in patients with obesity; likewise mechanically, obesity plays a fundamental role in cardiovascular risk factors. Perirenal adipose tissue could also contribute to the hypertension frequently observed in patients with obesity $[91,99]$. The increase in visceral fat [89] as well as the increase in liposomal size (steatosis) in the liver favor the accumulation of lipids in vacuoles and an increase in associated conditions such as non-alcoholic fatty liver, steatohepatitis, and cirrhosis $[62,100]$. Accordingly, in MS in which intra-abdominal visceral fat accumulation has an important role in the development of diabetes, lipid disorder, hypertension, and atherosclerosis, adipocytokines have key roles.

LEP regulates the release of most of the adipocytokines, inhibits the production of adiponectin (protective

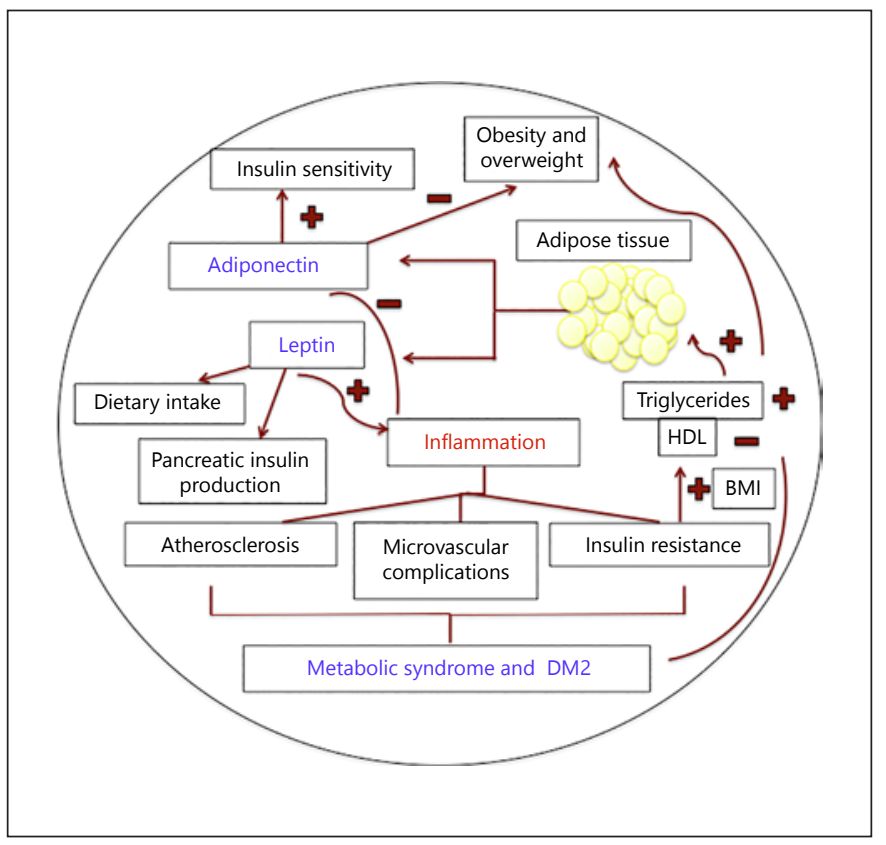

Fig. 2. Adiponectin, leptin, and metabolic syndrome. The association of leptin and adiponectin with metabolic syndrome, obesity, and overweight is shown.

hormone against the effects harmful to obesity), and stimulates the production of resistin, which induces resistance to insulin and LEP itself [62]. LEP, due to its proinflammatory function, is released as a regulatory mechanism of general metabolism, but the lack of control in risk factors such as obesity, sedentary lifestyle, and diet generates resistance to the role of this hormone, mediated in part by the hyperproduction of resistin, so it is produced in greater quantity and increases the causative effects of MS, which are the same as for adipocytokines TNF- $\alpha$ and IL-6. On the other hand, adiponectin, whose expression decreases in obesity, seems to have a protector role in MS development, mediated in part by visfatin, which surprisingly increases in obesity.

In summary, adiponectin and LEP are a crucial signal link between adiposity and metabolic disorders. LEP is not only a multifunctional metabolic regulator that alters food intake, energy expenditure, and neuroendocrine function but has also been described as an important mediator of obesity-related proinflammatory status that contributes to metabolic disorders including MS. On the other hand, adiponectin can improve metabolic status through anti-inflammatory effects, improving the effects of insulin sensitization and anti-arteriosclerosis [101103]. Typical obesity in humans is commonly associated with elevated LEP levels and decreased adiponectin levels, 
suggesting that there has been an imbalance in LEP-adiponectin regulation, and this imbalance may play a role in development of complications related to obesity. In previous population studies, hyperleptinemia or hypoadiponectinemia has been shown to be leading cause of metabolic disorders in both children and adults [101, 104-107]. Given the different roles of LEP and adiponectin in cardiometabolic disorders, it has been suggested that the imbalance of LEP-adiponectin regulation, as reflected by the circulating levels of LEP-to-adiponectin ratio (L/A), could potentially be a better indicator for diagnosis of MS than LEP or adiponectin alone. Several crosssectional studies in adults have compared the diagnostic value of L/A with that of LEP or adiponectin alone, and most studies supported the concept. In contrast, a small study in adults with DM2 reported that adiponectin performed better than L/A for the detection of MS. Particularly, a longitudinal study in Korean adults reported that L/A better predicted than adiponectin and LEP alone for the regression of MS in females and better than LEP in males [101]. Figures 1 and 2 show the relationship of adipocytokines (adiponectin and LEP) and their association with MS.

\section{Conclusions}

The pathophysiology of obesity and MS still have gaps in knowledge, despite having a high prevalence worldwide and to be pathologies that induce the development of CVDs with high morbidity and mortality rates.

In both obesity and MS, the main protagonist is adipose tissue and in particular the adipocyte whose physiological function is relevant in metabolic regulation, cell growth, response immune, thermogenesis, and reproductive and cardiovascular functions, among others, so the understanding of the alterations in this cell and in the molecules secreted by it is the starting point to determine the mechanisms and physiological conditions that lead to metabolic imbalance, primary cause of complications that cause high morbidity and mortality due to MS.

The study of MS and adipocytokines such as adiponectin and LEP in Colombia is of interest, especially in children and adolescents, who currently have bad habits, including overfeeding, excess weight (overweight and obesity), and sedentary lifestyle. Given that LEP and adiponectin have opposite effects on subclinical inflammation and IR, it was speculated that the combined use of those 2 adipokines may function as a better biomarker in the diagnosis of MS. However, due to the general burden of MS and its cardiometabolic consequences, more research is needed to elucidate the complex pathways involved in its pathogenesis.

\section{Acknowledgements and Funding Sources}

The authors wish to acknowledge the financial support of the project "Factores determinantes asociados a síndrome metabólico en población escolarizada de algunos municipios del Departamento de Cundinamarca" provided by the National Institute of Health of Colombia.

\section{Conflict of Interest Statement}

The authors declare no conflicts of interest.

\section{Author Contributions}

The authors are researches of the project "Factores determinantes asociados a síndrome metabólico en población escolarizada de algunos municipios del Departamento de Cundinamarca" under the same conditions. M.L.G.A. wrote the article and A.Y.F. made contributions at the nutritional level.

\section{References}

1 Megchún-Hernández M, Espinosa-Raya J, García-Parra E, Albavera-Hernández C, Briones-Aranda A. Asociación de indicadores antropométricos para evaluar el estado nutricional y el riesgo cardiometabólico en adolescentes mexicanos. Nutr Hosp. 2019;36(5) 1049-54.

2 Tejero ME. Genética de la obesidad. Bol Med Hosp Infant Méx. 2008;65:441-50.

3 Böttcher Y, Körner A, Kovacs P, Kiess W. Obesity genes: implication in childhood obesity. Paediatrics Child Health. 2012;22(1):31-

Adipocytokines in Metabolic Syndrome
4 O'Rahilly S. Human genetics illuminates the paths to metabolic disease. Nature. 2009; 462(7271):307-14.

5 Ulloa-Martínez M, Burguete-García AI, Murugesan S, Hoyo-Vadillo C, Cruz-Lopez M, García-Mena J. Expression of candidate genes associated with obesity in peripheral white blood cells of Mexican children. Arch Med Sci. 2016;12(5):968-76.

6 Herrera BM, Lindgren CM. The genetics of obesity. Curr Diab Rep. 2010;10(6):498-505.

7 Zhu J, Su X, Li G, Chen J, Tang B, Yang Y. The incidence of acute myocardial infarction in relation to overweight and obesity: a metaanalysis. Arch Med Sci. 2014;10(5):855-62.

8 Flegal KM, Carroll MD, Ogden CL, Curtin LR. Prevalence and trends in obesity among US adults, 1999-2008. JAMA. 2010;303(3):235-41.

9 Gunturiz ML, Forero AY, Chaparro PE. Genes implicated in obesity and overweight: potential biomarkers of early diagnosis. Curr Res Clin Diab Obes. 2018.

10 Shirai K. Obesity as the core of the metabolic syndrome and the management of coronary heart disease. Curr Med Res Opin. 2004; 20(3):295-304. 
11 Kumada M, Kihara S, Sumitsuji S, Kawamoto T, Matsumoto S, Ouchi N, et al. Association of hypoadiponectinemia with coronary artery disease in men. Arterioscler Thromb Vasc Biol. 2003;23(1):85-9.

12 Xu FP, Chen MS, Wang YZ, Yi Q, Lin SB, Chen $\mathrm{AF}$, et al. Leptin induces hypertrophy via endothelin-1-reactive oxygen species pathway in cultured neonatal rat cardiomyocytes. Circulation. 2004;110(10):1269-75.

13 Iglesias MJ, Eiras S, Piñeiro R, López-Otero D, Gallego R, Fernández AL, et al. [Gender differences in adiponectin and leptin expression in epicardial and subcutaneous adipose tissue. Findings in patients undergoing cardiac surgery]. Rev Esp Cardiol. 2006;59(12):125260.

14 Rodea-Montero ER, Evia-Viscarra ML, Apolinar-Jiménez E. Waist-to-height ratio is a better anthropometric index than waist circumference and BMI in predicting metabolic syndrome among obese Mexican adolescents. Int J Endocrinol. 2014;2014:195407.

15 Santomauro F, Lorini C, Pieralli F, Niccolai G, Picciolli P, Vezzosi S, et al. Waist-to-height ratio and its associations with body mass index in a sample of Tuscan children in primary school. Ital J Pediatr. 2017;43(1):53.

16 Valle-Leal J, Abundis-Castro L, HernándezEscareño J, Flores-Rubio S. Índice cintura-estatura como indicador de riesgo metabólico en niños Revista Chilena de Pediatría. 2016; 87(3):180-5.

17 Ahima RS, Lazar MA. Adipokines and the peripheral and neural control of energy balance. Mol Endocrinol. 2008;22(5):1023-31.

18 Chait A, den Hartigh LJ. Adipose tissue distribution, inflammation and its metabolic consequences, including diabetes and cardiovascular disease. Front Cardiovasc Med. 2020;7: 22.

19 Su X, Peng D. Adipokines as novel biomarkers of cardio-metabolic disorders. Clin Chim Acta. 2020;507:31-8.

20 Sánchez-Muñoz F, García-Macedo R, Alarcón-Aguilar F, Cruz M. Adipocinas, tejido adiposo y su relación con células del sistema inmune. Gac Méd Méx. 2005;141(6):50512.

21 Fukuhara A, Matsuda M, Nishizawa M, Segawa K, Tanaka M, Kishimoto K, et al. Visfatin: a protein secreted by visceral fat that mimics the effects of insulin. Science. 2005;307(5708): $426-30$.

22 Lee DK, George SR, O’Dowd BF. Unravelling the roles of the apelin system: prospective therapeutic applications in heart failure and obesity. Trends Pharmacol Sci. 2006;27(4): 190-4.

23 Tilg H, Moschen AR. Adipocytokines: mediators linking adipose tissue, inflammation and immunity. Nat Rev Immunol. 2006;6(10): $772-83$.

24 Scherer PE, Williams S, Fogliano M, Baldini G, Lodish HF. A novel serum protein similar to $\mathrm{C} 1 \mathrm{q}$, produced exclusively in adipocytes. Biol Chem. 1995;270(45):26746-9.
25 Mora S, Pessin JE. An adipocentric view of signaling and intracellular trafficking. Diabetes Metab Res Rev. 2002;18(5):345-56.

26 Pajvani UB, Du X, Combs TP, Berg AH, Rajala MW, Schulthess T, et al. Structure-function studies of the adipocyte-secreted hormone Acrp30/adiponectin. Implications fpr metabolic regulation and bioactivity. J Biol Chem. 2003;278(11):9073-85.

27 Yamauchi T, Kamon J, Ito Y, Tsuchida A, Yokomizo T, Kita S, et al. Cloning of adiponectin receptors that mediate antidiabetic metabolic effects. Nature. 2003;423(6941):762-9.

28 Piñeiro R, Iglesias MJ, Gallego R, Raghay K, Eiras S, Rubio J, et al. Adiponectin is synthesized and secreted by human and murine cardiomyocytes. FEBS Lett. 2005:579(23):51639.

29 Arita Y, Kihara S, Ouchi N, Takahashi M, Maeda K, Miyagawa J, et al. Paradoxical decrease of an adipose-specific protein, adiponectin, in obesity. Biochem Biophys Res Commun. 1999;257(1):79-83.

30 Ukkola O, Santaniemi M. Adiponectin: a link between excess adiposity and associated comorbidities? J Mol Med. 2002;80(11):696702.

31 Berg AH, Combs TP, Scherer PE. ACRP30/ adiponectin: an adipokine regulating glucose and lipid metabolism. Trends Endocrinol Metab. 2002;13(2):84-9.

32 Díez JJ, Iglesias P. The role of the novel adipocyte-derived hormone adiponectin in human disease. Eur J Endocrinol. 2003;148(3):293300.

33 Beltowski J. Adiponectin and resistin: new hormones of white adipose tissue. Med Sci Monit. 2003;9(2):RA55-61.

34 Ouchi N, Kihara S, Arita Y, Okamoto Y, Maeda K, Kuriyama H, et al. Adiponectin, an adipocyte-derived plasma protein, inhibits endothelial NF-kappaB signaling through a cAMP-dependent pathway. Circulation. 2000;102(11):1296-301.

35 González-Juanatey JR, Paz FL, Eiras S, Teijeira-Fernández E. Adipocitocinas como nuevos marcadores de la enfermedad cardiovascular. Perspectivas fisiopatológicas y clínicas. Revista Española de Cardiología. 2009;62(S2):916.

36 Kadowaki T, Yamauchi T, Kubota N, Hara K, Ueki K. Adiponectin and adiponectin receptors in obesity-linked insulin resistance. Novartis Found Symp. 2005;286:164-3.

37 Ding G, Qin Q, He N, Francis-David SC, Hou J, Liu J, et al. Adiponectin and its receptors are expressed in adult ventricular cardiomyocytes and upregulated by activation of peroxisome proliferator-activated receptor gamma. J Mol Cell Cardiol. 2007;43(1):73-84.

38 Yoon MJ, Lee GY, Chung JJ, Ahn YH, Hong $\mathrm{SH}, \mathrm{Kim}$ JB. Adiponectin increases fatty acid oxidation in skeletal muscle cells by sequential activation of AMP-activated protein kinase, p38 mitogen-activated protein kinase, and peroxisome proliferator-activated receptor alpha. Diabetes. 2006;55(9):2562-70.
39 Palomer X, Pérez A, Blanco-Vaca F. Adiponectina: un nuevo nexo entre obesidad, resistencia a la insulina y enfermedad cardiovascular. Medicina Clínica. 2005;124(10):388-95.

40 Shibata R, Sato K, Pimentel DR, Takemura Y, Kihara S, Ohashi K, et al. Adiponectin protects against myocardial ischemia-reperfusion injury through AMPK- and COX-2-dependent mechanisms. Nat Med. 2005;11(10): 1096-103.

41 Shibata R, Izumiya Y, Sato K, Papanicolaou K, Kihara S, Colucci WS, et al. Adiponectin protects against the development of systolic dysfunction following myocardial infarction. J Mol Cell Cardiol. 2007;42(6):1065-74.

42 Chow WS, Cheung BM, Tso AW, Xu A, Wat $\mathrm{NM}$, Fong $\mathrm{CH}$, et al. Hypoadiponectinemia as a predictor for the development of hypertension: a 5-year prospective study. Hypertension. 2007;49(6):1455-61.

43 Iwashima Y, Katsuya T, Ishikawa K, Ouchi N, Ohishi M, Sugimoto K, et al. Hypoadiponectinemia is an independent risk factor for hypertension. Hypertension. 2004;43(6):131823.

44 Stroescu RF, Mărginean O, Bizerea T, Gafencu M, Voicu A, Doroș G. Adiponectin, leptin and high sensitivity $\mathrm{C}$-reactive protein values in obese children: important markers for metabolic syndrome? J Pediatr Endocrinol Metab. 2019;32(1):27-31.

45 Pischon T, Girman CJ, Hotamisligil GS, Rifai N, Hu FB, Rimm EB. Plasma adiponectin levels and risk of myocardial infarction in men. JAMA. 2004;291(14):1730-7.

46 Wolk R, Berger P, Lennon RJ, Brilakis ES, Davison DE, Somers VK. Association between plasma adiponectin levels and unstable coronary syndromes. Eur Heart J. 2007;28(3):292-8.

47 Schulze MB, Shai I, Rimm EB, Li T, Rifai N, $\mathrm{Hu} \mathrm{FB}$. Adiponectin and future coronary heart disease events among men with type 2 diabetes. Diabetes. 2005;54(2):534-9.

48 Kojima S, Funahashi T, Sakamoto T, Miyamoto S, Soejima H, Hokamaki J, et al. The variation of plasma concentrations of a novel, adipocyte derived protein, adiponectin, in patients with acute myocardial infarction. Heart. 2003;89(6):667.

49 Otsuka F, Sugiyama S, Kojima S, Maruyoshi $\mathrm{H}$, Funahashi T, Matsui K, et al. Plasma adiponectin levels are associated with coronary lesion complexity in men with coronary artery disease. J Am Coll Cardiol. 2006;48(6): 1155-62.

50 Cavusoglu E, Ruwende C, Chopra V, Yanamadala S, Eng C, Clark LT, et al. Adiponectin is an independent predictor of all-cause mortality, cardiac mortality, and myocardial infarction in patients presenting with chest pain. Eur Heart J. 2006;27(19):2300-9.

51 Schnabel R, Messow CM, Lubos E, EspinolaKlein C, Rupprecht HJ, Bickel C, et al. Association of adiponectin with adverse outcome in coronary artery disease patients: results from the AtheroGene study. Eur Heart J. 2008;29(5):649-57. 
52 Friedman JM, Halaas JL. Leptin and the regulation of body weight in mammals. Nature. 1998;395(6704):763-70.

53 Friedman JM. A tale of two hormones. Nat Med. 2010;16(10):1100-6.

54 Oral EA, Simha V, Ruiz E, Andewelt A, Premkumar A, Snell P, et al. Leptin-replacement therapy for lipodystrophy. N Engl J Med. 2002;346(8):570-8.

55 Madej T, Boguski MS, Bryant SH. Threading analysis suggests that the obese gene product may be a helical cytokine. FEBS Lett. 1995; 373(1):13-8.

56 Tartaglia LA, Dembski M, Weng X, Deng N, Culpepper J, Devos R, et al. Identification and expression cloning of a leptin receptor, OB-R. Cell. 1995;83(7):1263-71.

57 Goldenberg D, Santos JL, Hodgson MI, Cortés VA. Nuevas proyecciones fisiológicas, patológicas y terapéuticas de la leptina. Rev Méd Chile. 2014;142(6):738-47.

58 Masuzaki H, Ogawa Y, Sagawa N, Hosoda K Matsumoto T, Mise H, et al. Nonadipose tissue production of leptin: leptin as a novel placenta-derived hormone in humans. Nat Med. 1997;3(9):1029-33.

59 Bado A, Levasseur S, Attoub S, Kermorgant S, Laigneau JP, Bortoluzzi MN, et al. The stomach is a source of leptin. Nature. 1998 394(6695):790-3.

60 Bjørbaek C, Elmquist JK, Michl P, Ahima RS, van Bueren A, McCall AL, et al. Expression of leptin receptor isoforms in rat brain microvessels. Endocrinology. 1998;139(8): 3485-91.

61 Myers MG Jr. Leptin keeps working, even in obesity. Cell Metab. 2015;21(6):791-2.

62 Gómez A, Palacio J, Jaramillo A, Rosero R. Leptina: más que una adipocina, una herramienta para la comprensión de la obesidad y el riesgo cardiovascular. 2018.

63 Considine RV, Sinha MK, Heiman ML, Kriauciunas A, Stephens TW, Nyce MR, et al. Serum immunoreactive-leptin concentrations in normal-weight and obese humans. N Engl J Med. 1996;334(5):292-5.

64 Pittas AG, Joseph NA, Greenberg AS. Adipocytokines and insulin resistance. J Clin Endocrinol Metab. 2004;89(2):447-52.

65 Shimabukuro M, Koyama K, Chen G, Wang MY, Trieu F, Lee Y, et al. Direct antidiabetic effect of leptin through triglyceride depletion of tissues. Proc Natl Acad Sci U S A. 1997; 94(9):4637-41.

66 Muoio DM, Dohm GL, Fiedorek FT Jr, Tapscott EB, Coleman RA, Dohn GL. Leptin directly alters lipid partitioning in skeletal muscle. Diabetes. 1997;46(8):1360-3

67 Minokoshi Y, Kim YB, Peroni OD, Fryer LG, Müller C, Carling D, et al. Leptin stimulates fatty-acid oxidation by activating AMP-activated protein kinase. Nature. 2002;415(6869):339-43.

68 Shimomura I, Hammer RE, Ikemoto S, Brown MS, Goldstein JL. Leptin reverses insulin resistance and diabetes mellitus in mice with congenital lipodystrophy. Nature. 1999; 401(6748):73-6.
69 Ebihara K, Ogawa Y, Masuzaki H, Shintani M, Miyanaga F, Aizawa-Abe M, et al. Transgenic overexpression of leptin rescues insulin resistance and diabetes in a mouse model of lipoatrophic diabetes. Diabetes. 2001;50(6): $1440-8$.

70 Bjørbaek C, El-Haschimi K, Frantz JD, Flier JS. The role of SOCS-3 in leptin signaling and leptin resistance. J Biol Chem. 1999;274(42): 30059-65.

71 Gainsford T, Willson TA, Metcalf D, Handman E, McFarlane C, Ng A, et al. Leptin can induce proliferation, differentiation, and functional activation of hemopoietic cells. Proc Natl Acad Sci U S A. 1996;93(25):14564-8.

72 Fernandes G, Handwerger BS, Yunis EJ, Brown DM. Immune response in the mutant diabetic C57BL/Ks-dt+ mouse. Discrepancies between in vitro and in vivo immunological assays. J Clin Invest. 1978;61(2):243-50.

73 Chandra RK. Cell-mediated immunity in genetically obese C57BL/6J ob/ob) mice. Am J Clin Nutr. 1980;33(1):13-6.

74 Pickup JC, Crook MA. Is type II diabetes mellitus a disease of the innate immune system? Diabetologia. 1998;41(10):1241-8.

75 Ahima RS, Flier JS. Adipose tissue as an endocrine organ. Trends Endocrinol Metab. 2000; 11(8):327-32.

76 Segal KR, Landt M, Klein S. Relationship between insulin sensitivity and plasma leptin concentration in lean and obese men. Diabetes. 1996;45(7):988-91.

77 De Courten M, Zimmet P, Hodge A, Collins V, Nicolson M, Staten M, et al. Hyperleptinaemia: the missing link in the, metabolic syndrome? Diabet Med. 1997;14(3):200-8.

78 Zimmet PZ, Collins VR, De Courten MP, Hodge AM, Collier GR, Dowse GK, et al. Is there a relationship between leptin and insulin sensitivity independent of obesity? A population-based study in the Indian Ocean nation of Mauritius. Mauritius NCD Study Group. Int J Obes Relat Metab Disord. 1998;22(2):171-7.

79 Wallace AM, McMahon AD, Packard CJ, Kelly A, Shepherd J, Gaw A, et al. Plasma leptin and the risk of cardiovascular disease in the west of Scotland coronary prevention study (WOSCOPS). Circulation. 2001;104(25): 3052-6.

80 Morales Clavijo M, Carvajal Garcés CF. Obesidad y resistencia a la leptina. Gac Med Bol. 2010;33(1):63-8.

81 García García E. Síndrome metabólico en Pediatría. En AEPap ed. Curso de Actualización Pediatría. Madrid: Exlibris Ediciones; 2013.p. 323-35.

82 Gunturiz ML. Metabolic syndrome and cardiovascular implications in younger people. Ther Adv Cardiol. 2017;1(4):188-98.

83 Grundy SM, Cleeman JI, Daniels SR, Donato KA, Eckel RH, Franklin BA, et al. Diagnosis and management of the metabolic syndrome: an American Heart Association/National Heart, Lung, and Blood Institute scientific statement: executive summary. Crit Pathw Cardiol. 2005;4(4):198-203.
84 Alberti KGMM, Eckel RH, Grundy SM, Zimmet PZ, Cleeman JI, Donato KA, et al. Harmonizing the metabolic syndrome. Circulation. 2009;120(16):1640-5

85 He X, Zhang W, Pang G, Lv Y, Hu C, Yang Z. Prevalence and clinical profile of metabolic syndrome in longevity: study from Guangxi Zhuang Autonomous Region, China. BMC Geriatr. 2017;17(1):169.

86 Alpízar Caballero L. El síndrome metabólico en niños y adolescentes. Revista Cubana de Medicina Militar. 2013;42(4):464-71.

87 Weiss R, Dziura J, Burgert TS, Tamborlane WV, Taksali SE, Yeckel CW, et al. Obesity and the metabolic syndrome in children and adolescents. N Engl J Med. 2004;350(23):236274.

$88 \mathrm{Li}$, Yu X, Pan W, Unger RH. Gene expression profile of rat adipose tissue at the onset of high-fat-diet obesity. Am J Physiol Endocrinol Metab. 2002;282(6):E1334-41.

$89 \mathrm{Wu}$ J, Cohen P, Spiegelman BM. Adaptive thermogenesis in adipocytes: is beige the new brown? Genes Dev. 2013;27(3):234-50.

90 Calle EE, Thun MJ. Obesity and cancer. Oncogene. 2004;23(38):6365-78.

91 Creely SJ, McTernan PG, Kusminski CM, Fisher fM, Da Silva NF, Khanolkar M, et al. Lipopolysaccharide activates an innate immune system response in human adipose tissue in obesity and type 2 diabetes. Am J Physiol Endocrinol Metab. 2007;292(3):E740-7.

92 Skurk T, Alberti-Huber C, Herder C, Hauner $\mathrm{H}$. Relationship between adipocyte size and adipokine expression and secretion. J Clin Endocrinol Metab. 2007;92(3):1023-33.

93 Sánchez JC, López DF, Pinzón OA, Sepúlveda JC. Adipocinas y síndrome metabólico: múltiples facetas de un proceso fisiopatológico complejo. Rev Colomb Cardiol. 2010;17(4):167-76.

94 Lago F, Dieguez C, Gómez-Reino J, Gualillo $\mathrm{O}$. The emerging role of adipokines as mediators of inflammation and immune responses. Cytokine Growth Factor Rev. 2007;18(3-4): 313-25.

95 Blüher M, Bullen JW Jr, Lee JH, Kralisch S, Fasshauer M, Klöting N, et al. Circulating adiponectin and expression of adiponectin receptors in human skeletal muscle: associations with metabolic parameters and insulin resistance and regulation by physical training. J Clin Endocrinol Metab. 2006;91(6):2310-6.

96 Yamauchi T, Kamon J, Minokoshi Y, Ito Y, Waki H, Uchida S, et al. Adiponectin stimulates glucose utilization and fatty-acid oxidation by activating AMP-activated protein kinase. Nat Med. 2002;8(11):1288-95.

97 Yamauchi T, Nio Y, Maki T, Kobayashi M, Takazawa T, Iwabu M, et al. Targeted disruption of AdipoR1 and AdipoR2 causes abrogation of adiponectin binding and metabolic actions. Nat Med. 2007;13(3):332-9.

98 Gualillo O, González-Juanatey JR, Lago F. The emerging role of adipokines as mediators of cardiovascular function: physiologic and clinical perspectives. Trends Cardiovasc Med. 2007;17(8):275-83. 
99 Kaur J A comprehensive review on metabolic syndrome. Cardiol Res Pract. 2014;2014: 943162.

100 McCullough AJ. The clinical features, diagnosis and natural history of nonalcoholic fatty liver disease. Clin Liver Dis. 2004;8(3): 521-33,

101 Li G, Xu L, Zhao Y, Li L, Fu J, Zhang Q, et al. Leptin-adiponectin imbalance as a marker of metabolic syndrome among Chinese children and adolescents: the BCAMS study. PLoS One. 2017;12(10):e0186222.

102 Fasshauer M, Blüher M. Adipokines in health and disease. Trends Pharmacol Sci. 2015;36(7):461-70.
103 Pérez-Pérez A, Vilariño-García T, Fernández-Riejos P, Martín-González J, SeguraEgea JJ, Sánchez-Margalet V. Role of leptin as a link between metabolism and the immune system. Cytokine Growth Factor Rev. 2017;35:71-84

104 Sáinz N, Barrenetxe J, Moreno-Aliaga MJ, Martínez JA. Leptin resistance and diet-induced obesity: central and peripheral actions of leptin. Metab Clin Exp. 2015;64(1):35-46.

105 Erhardt E, Foraita R, Pigeot I, Barba G, Veidebaum T, Tornaritis M, et al. Reference values for leptin and adiponectin in children below the age of 10 based on the IDEFICS cohort. Int J Obes. 2014;38(Suppl 2):S32-8.
106 Cambuli VM, Musiu MC, Incani M, Paderi M, Serpe R, Marras V, et al. Assessment of adiponectin and leptin as biomarkers of positive metabolic outcomes after lifestyle intervention in overweight and obese children. J Clin Endocrinol Metab. 2008;93(8):3051-7.

107 Alikaşifoğlu A, Gönç N, Özön ZA, Sen Y, Kandemir N. The relationship between serum adiponectin, tumor necrosis factor-alpha, leptin levels and insulin sensitivity in childhood and adolescent obesity: adiponectin is a marker of metabolic syndrome. J Clin Res Pediatr Endocrinol. 2009;1(5):233-9. 